\title{
Implementasi Pendidikan Karakter di Sekolah Dasar Melalui Penguatan Pelaksanaan Kurikulum
}

\author{
Sri Judiani \\ Setditjen Manajemen Pendidikan Dasar dan Menengah, Kemendiknas \\ email: srijudiani@yahoo.com
}

\begin{abstract}
Abstrak: Saat ini pelajar Indonesia semakin banyak yang patut dibanggakan, karena telah berhasil menjuarai olimpiade sains di tingkat internasional. Bahkan, pelajar Indonesia menjadi juara umum dalam Konferensi Internasional IImuwan Muda se-Dunia yang diikuti ratusan pelajar SMA dari 19 negara di Bali pada 12-17 April 2010. Namun, tidak sedikit pula pelajar yang tidak punya sopan santun, suka tawuran, minum minuman keras, mabok-mabokan, senang narkotika, dan hobi kebut-kebutan mengendarai sepeda motor di jalan raya. Melihat kenyataan ini maka Pemerintah mulai tahun ajaran 2010 telah melakukan piloting penyelenggaraan pendidikan karakter di 125 sekolah yang tersebar di 16 kabupaten/kota dari 16 Propinsi. Implementasi pendidikan karakter di sekolah tidak merupakan mata pelajaran tersendiri, tidak pula merupakan tambahan standar kompetensi (SK) dan kompetensi dasar (KD), tetapi dapat diintegrasikan ke dalam mata pelajaran yang sudah ada, pengembangan diri, dan budaya sekolah, serta muatan lokal.
\end{abstract}

Kata kunci: pendidikan, karakter, terintegrasi, pengembangan diri, budaya sekolah, dan muatan lokal.

\begin{abstract}
Nowadays we should be proud because the more Indonesian students have succeeded in International Science Olympic. The Indonesian student team was even once to be overall champion in the International Conference of Young Scientists with participant from 19 countries held in Bali on April 12th- $7^{\text {th }}$ 2010. On the other hand, some other Indonesian students have shown their disrespectful attitude to public, they like to brawl or fight with the student from other school, get drunk, drugs or narcotic addiction, wild races along the crowded traffic. The phenomenon is then to be the reason for government to conduct "Piloting Project" in 125 schools in 16 districts/cities in within 16 provinces since September 2010. The Objectives of conducting the "Piloting Projects" is to implement the values of character to the students so they can turn their attitude to the positive one. The implementation of character education does not need to be the typical subject nor additional standard of competence but this is, however, integrated into the existing subject or through the self-development and school culture as well as local content.
\end{abstract}

Key words: education, character, integrated, self-development, school culture, and local content.

\section{Pendahuluan}

Siapa yang tidak mengelus dada melihat pelajar yang tidak punya sopan santun, suka tawuran, minum minuman keras, mabok-mabokan, senang narkotika, dan hobi begadang serta kebut-kebutan mengendarai motor di jalan raya? Ini jenis kenakalan pelajar yang paling umum, sedangkan kenakalan lainnya seperti mencontek, menjiplak karya orang lain, melakukan sabotase, vandalisme halaman buku perpustakaan, membolos sekolah, mencuri, berjudi, dan banyak lagi.
Namun, pelajar yang patut dibanggakan juga ada, seperti mereka yang menjuarai olimpiade sains, baik di tingkat nasional maupun internasional. Bahkan, pelajar Indonesia menjadi juara umum dalam International Conference of Young Scientists (ICYS) atau Konferensi Internasional Ilmuwan Muda se-Dunia yang diikuti ratusan pelajar SMA dari 19 negara di Bali pada $12-17$ April 2010.

Mencontek telah menjadi budaya lembaga pendidikan kita. Hal ini bukan hanya berkaitan 
dengan kelemahan individu per individu, melainkan telah membentuk sebuah kultur sekolah yang tidak menghargai kejujuran. Masifnya perilaku ketidakjujuran ini telah merambah dalam diri siswa, pendidik, dan anggota komunitas sekolah.

Pembangunan karakter dan pendidikan karakter menjadi suatu keharusan karena pendidikan tidak hanya menjadikan peserta didik menjadi cerdas, juga mempunyai budi pekerti dan sopan santun, sehingga keberadaannya sebagai anggota masyarakat menjadi bermakna baik bagi dirinya maupun orang lain. Pembinaan karakter yang termudah dilakukan adalah ketika anak-anak masih duduk di bangku SD. Itulah sebabnya pemerintah memprioritaskan pendidikan karakter di SD. Bukan berarti pada jenjang pendidikan lainnya tidak mendapat perhatian namun porsinya saja yang berbeda (Mendiknas, 2010).

Pendidikan karakter yang diterapkan di sekolah-sekolah tidak diajarkan dalam mata pelajaran khusus. Namun, dilaksanakan melalui keseharian pembelajaran yang sudah berjalan di sekolah. Wakil Mendiknas, Fasli Jalal, mengatakan pendidikan karakter yang didorong pemerintah untuk dilaksanakan di sekolah-sekolah tidak akan membebani guru dan siswa. Sebab, nilai-nilai yang terkandung dalam pendidikan karakter sebenarnya sudah ada dalam kurikulum, namun selama ini tidak dikedepankan dan diajarkan secara tersurat. Kita mintakan pada guru supaya nilainilai yang terkandung dalam mata pelajaran maupun dalam kegiatan ekstra kurikuler disampaikan dengan jelas pada siswa. Pendidikan karakter bisa terintegrasi juga menjadi budaya sekolah. Jadi, pendidikan karakter yang hendak diterapkan secara nasional tidak membebani kurikulum yang ada saat ini. Pendidikan karakter yang dikembangkan adalah yang dapat membangun wawasan kebangsaan serta mendorong inovasi dan kreasi siswa. Selain itu, nilai-nilai yang perlu dibangun dalam diri generasi penerus bangsa secara nasional yakni kejujuran, kerja keras, menghargai perbedaan, kerjasama, toleransi, dan disiplin. Sekolah bebas untuk memilih dan menerapkan nilai-nilai yang hendak dibangun dalam diri siswa. Bahkan pemerintah mendorong munculnya keragaman untuk pelaksanaan pendidikan karakter. Program-program di sekolah seperti pramuka, kantin kejujuran, sekolah hijau, olimpiade sains dan seni, serta kesenian tradisional, misalnya, telah sarat dengan pendidikan karakter. Tinggal guru yang mesti memunculkan nilai-nilai dalam program itu sebagai bagian dari pendidikan karakter di sekolah (Fasli Jalal, 2010a). Untuk menerapkan pendidikan karakter, seluruh warga sekolah harus memiliki kesepakatan tentang nilai-nilai karakter yang akan dikembangkan di sekolahnya (Anita Lie, 2010b).

Selanjutnya, Anita Lie juga menyatakan bahwa pendidikan karakter tidak merupakan mata pelajaran yang berdiri sendiri, tetapi harus diintegrasikan dalam kurikulum, artinya menjadi penguat kurikulum yang sudah ada, yaitu dengan mengimplementasikannya dalam mata pelajaran dan keseharian anak didik. Mata pelajaran biologi misalnya, siswa diajak langsung menanam tumbuh-tumbuhan, diberi pemahaman tentang manfaatnya, dikaitkan dengan kerusakan lingkungan, dan sebagainya. Pada mata pelajaran kesenian, siswa diajak mengenal dan mempraktekkan beragam peninggalan seni budaya yang menjadi muatan lokal, falsafah budaya, dan manfaatnya. Masalahnya. Mayoritas guru belum punya kemauan untuk melakukan itu. Kesadaran sudah ada, hanya saja belum diujudkan menjadi sebuah aksi nyata. Hal ini disebabkan pendidikan di Indonesia masih terfokus pada aspek-aspek kognitif atau akademik, sedangkan aspek soft skills atau non-akademik yang merupakan unsur utama pendidikan karakter selama ini masih kurang mendapatkan perhatian.

Berdasar latar belakang masalah di atas, maka permasalahan yang dikaji di sini dapat dirumuskan sebagai berikut: "Bagaimanakah implementasi pendidikan karakter bangsa di sekolah dasar? Adapun tujuan penulisan artikel dimaksudkan untuk memberikan gambaran secara umum tentang implementasi pendidikan karakter bangsa di sekolah dasar sehingga dapat digunakan sebagai referensi para pembaca terutama para guru dan kepala sekolah ketika mengimplementasikan pendidikan karakter di sekolahnya masing-masing.

\section{Kajian Literatur dan Pembahasan Tujuan Pendidikan dan Kompetensi Lulusan}

Dalam Undang-Undang Nomor 20 Tahun 2003 tentang Sistim Pendidikan Nasional disebutkan 
bahwa Pendidikan Nasional berdasarkan Pancasila dan Undang-Undang Dasar Negara Republik Indonesia Tahun 1945 (Pasal 2), berfungsi mengembangkan kemampuan dan membentuk watak serta peradaban bangsa yang bermartabat dalam rangka mencerdaskan kehidupan bangsa, bertujuan untuk berkembangnya potensi peserta didik agar menjadi manusia yang beriman dan bertakwa kepada Tuhan Yang Maha Esa, berakhlak mulia, sehat, berilmu, cakap, kreatif, mandiri, dan menjadi warga negara yang demokratis serta bertanggung jawab (Pasal 3).

Selanjutnya, dalam Peraturan Menteri Pendidikan Nasional Nomor 23 Tahun 2006 tentang Standar Kompetensi Lulusan dinyatakan bahwa Pendidikan Dasar bertujuan meletakkan dasar kecerdasan, pengetahuan, kepribadian, akhlak mulia, serta keterampilan untuk hidup mandiri dan mengikuti pendidikan lebih lanjut.

Kemudian dijelaskan bahwa Standar Kompetensi Lulusan Sekolah Dasar adalah: 1) Menjalankan ajaran agama yang dianut sesuai dengan tahap perkembangan anak; 2) Mengenal kekurangan dan kelebihan diri sendiri; 3) Mematuhi aturan-aturan sosial yang berlaku dalam lingkungannya; 4) Menghargai keberagaman agama, budaya, suku, ras, dan golongan sosial ekonomi di lingkungan sekitarnya; 5) Menggunakan informasi tentang lingkungan sekitar secara logis, kritis, dan kreatif; 6) Menunjukkan kemampuan berpikir logis, kritis, dan kreatif; dengan bimbingan guru/pendidik; 7) Menunjukkan rasa keingintahuan yang tinggi dan menyadari potensinya; 8) Menunjukkan kemampuan memecahkan masalah sederhana dalam kehidupan sehari-hari; 9) Menunjukkan kemampuan mengenali gejala alam dan sosial di lingkungan sekitar; 10) Menunjukkan kecintaan dan kepedulian terhadap lingkungan; 11) Menunjukkan kecintaan dan kebanggaan terhadap bangsa, negara, dan tanah air Indonesia; 12) Menunjukkan kemampuan untuk melakukan kegiatan seni dan budaya lokal; 13) Menunjukkan kebiasaan hidup bersih, sehat, bugar, aman, dan memanfaatkan waktu luang; 14) Berkomunikasi secara jelas dan santun; 15) Bekerja sama dalam kelompok, tolong menolong, dan menjaga diri sendiri dalam lingkungan keluarga dan teman sebaya; 16) Menunjukkan kegemaran membaca dan menulis; dan 17)
Menunjukkan keterampilan menyimak, berbicara, membaca, menulis, dan berhitung.

Mencermati tujuan pendidikan nasional, tujuan pendidikan dasar, dan standar kompetensi lulusan sekolah dasar, semua sarat dengan nilainilai karakter (bandingkan dengan Tabel 1. Nilai dan Deskripsi Nilai Pendidikan Karakter), namun sayangnya sebagian besar sekolah belum mengimplementasikannya. Oleh karena hal ini merupakan amanah dari peraturan perundangan, maka tidak ada alasan lagi untuk tidak mengimplementasikan pendidikan karaktrer di setiap sekolah.

\section{Pendidikan Karakter}

Istilah karakter berasal dari bahasa Yunani "charassein" yang berarti mengukir. Membentuk karakter diibaratkan seperti mengukir batu permata atau permukaan besi yang keras. Maka selanjutnya berkembang pengertian karakter yang diartikan sebagai tanda khusus atau pola perilaku (Bohlin, Farmer, \& Ryan, 2001). Dalam Kamus Bahasa Indonesia (2008) karakter didefinisikan sebagai sifat-sifat kejiwaan, akhlak, atau budi pekerti yang membedakan seseorang dari orang lain. Sedangkan menurut Philips (2008) karakter adalah kumpulan tata nilai yang menuju pada suatu system, yang melandasi pemikiran, sikap, dan perilaku yang ditampilkan.

Dari definisi para ahli, Fasli Jalal, dalam Kebijakan Nasional Pembangunan Karakter Bangsa (2010a) merumuskan definisi karakter sebagai nilai-nilai yang khas-baik (tahu nilai kebaikan, mau berbuat baik, nyata berkehidupan baik, dan berdampak baik terhadap lingkungan) yang terpatri dalam diri dan terejawantahkan dalam perilaku.

Pendidikan karakter dimaknai sebagai pendidikan yang mengem-bangkan nilai-nilai karakter pada diri peserta didik sehingga mereka memiliki nilai dan karakter sebagai karakter dirinya, menerapkan nilai-nilai tersebut dalam kehidupan dirinya, sebagai anggota masyarakat dan warganegara yang religius, nasionalis, produktif, dan kreatif (Pusat Kurikulum, 2010).

Fungsi pendidikan karakter adalah: 1) pengembangan; 2) perbaikan; dan 3) penyaring. Pengembangan, yakni pengembangan potensi peserta didik untuk menjadi pribadi berperilaku baik, terutama bagi peserta didik yang telah 
memiliki sikap dan perilaku yang mencerminkan karakter bangsa. Perbaikan, yakni memperkuat kiprah pendidikan nasional untuk bertanggung jawab dalam pengembangan potensi peserta didik yang lebih bermartabat. Penyaring, yaitu untuk menseleksi budaya bangsa sendiri dan budaya bangsa lain yang tidak sesuai dengan nilainilai karakter yang bermartabat.

Tujuan pendidikan karakter adalah: 1) mengembangkan potensi kalbu/nurani/afektif peserta didik sebagai manusia dan warganegara yang memiliki nilai-nilai karakter bangsa; 2) mengembangkan kebiasaan dan perilaku peserta didik yang terpuji dan sejalan dengan nilai-nilai universal dan tradisi budaya bangsa yang religius; 3) menanamkan jiwa kepemimpinan dan tanggung jawab peserta didik sebagai generasi penerus bangsa; 4) mengembangkan kemampuan peserta didik menjadi manusia yang mandiri, kreatif, berwawasan kebangsaan; dan 5) mengembangkan lingkungan kehidupan sekolah sebagai lingkungan belajar yang aman, jujur, penuh kreativitas dan persahabatan, serta dengan rasa kebangsaan yang tinggi dan penuh kekuatan.

Nilai-nilai yang dikembangkan dalam pendidikan karakter bersumber dari: 1) Agama, 2) Pancasila, 3) Budaya, dan 4) Tujuan Pendidikan Nasional (Pusat Kurikulum, 2010).

Agama: masyarakat Indonesia adalah masyarakat beragama. Oleh karena itu, kehidupan individu, masyarakat, dan bangsa selalu didasari pada ajaran agama dan kepercayaannya. Secara politis, kehidupan kenegaraan pun didasari pada nilai-nilai yang berasal dari agama. Atas dasar pertimbangan itu, maka nilainilai pendidikan karakter harus didasarkan pada nilai-nilai dan kaidah yang berasal dari agama.

Pancasila: negara kesatuan Republik Indonesia ditegakkan atas prinsip-prinsip kehidupan kebangsaan dan kenegaraan yang disebut Pancasila. Pancasila terdapat pada Pembukaan UUD 1945 dan dijabarkan lebih lanjut dalam pasal-pasal yang terdapat dalam UUD 1945. Artinya, nilai-nilai yang terkandung dalam Pancasila menjadi nilai-nilai yang mengatur kehidupan politik, hukum, ekonomi, kemasyarakatan, budaya, dan seni. Pendidikan budaya dan karakter bangsa bertujuan mempersiapkan peserta didik menjadi warga negara yang lebih baik, yaitu warga negara yang memiliki kemampuan, kemauan, dan menerapkan nilai-nilai Pancasila dalam kehidupannya sebagai warga negara.

Budaya: sebagai suatu kebenaran bahwa tidak ada manusia yang hidup bermasyarakat yang tidak didasari oleh nilai-nilai budaya yang diakui masyarakat itu. Nilai-nilai budaya itu dijadikan dasar dalam pemberian makna terhadap suatu konsep dan arti dalam komunikasi antaraanggota masyarakat itu. Posisi budaya yang demikian penting dalam kehidupan masyarakat mengharuskan budaya menjadi sumber nilai dalam pendidikan budaya dan karakter bangsa.

Tujuan Pendidikan Nasional: sebagai rumusan kualitas yang harus dimiliki setiap warga negara Indonesia, dikembangkan oleh berbagai satuan pendidikan di berbagai jenjang dan jalur. Tujuan pendidikan nasional memuat berbagai nilai kemanusiaan yang harus dimiliki warga negara Indonesia. Oleh karena itu, tujuan pendidikan nasional adalah sumber yang paling operasional dalam pengembangan pendidikan budaya dan karakter bangsa.

Berdasarkan keempat sumber nilai itu, teridentifikasi sejumlah nilai untuk pendidikan karakter bangsa sebagai berikut (Pusat Kurikulum, 2010).

Sekolah bebas untuk memilih dan menerapkan nilai-nilai mana dulu yang hendak dibangun dalam diri siswa. Bahkan pemerintah mendorong munculnya keragaman untuk pelaksanaan pendidikan karakter (Fasli Jalal, 2010a). Di sekolah A dapat saja mendahulukan nilai-nilai religius, sekolah B memprioritaskan nilai-nilai kejujuran, sekolah C memprioritaskan nilai-nilai toleransi, sedangkan di sekolah D sudah melaksanakan nilai-nilai religius, kejujuran, toleransi, dan kedisiplinan. Namun, sebaiknya untuk menerapkan pendidikan karakter, seluruh warga sekolah harus memiliki kesepakatan tentang nilai-nilai karakter yang akan dikembangkan di sekolahnya (Anita Lie, 2010a). Bila nilai-nilai karakter yang sudah disepakati untuk dikembangkan sudah diimplementasikan maka selanjutnya ditambah dengan nilai-nilai karakter yang lain untuk diimplementasikan, demikian seterusnya, sampai pada suatu saat semua nilai-nilai karakter sudah diimplementasikan di sekolah dan di luar sekolah. 
Tabel 1. Nilai dan Deskripsi Nilai Pendidikan Karakter

\begin{tabular}{|c|c|c|}
\hline No. & Nilai & Deskripsi \\
\hline 1. & Religius & $\begin{array}{l}\text { Sikap dan perilaku yang patuh dalam melaksanakan ajaran agama yang } \\
\text { dianutnya, toleran terhadap pelaksanaan ibadah agama lain, dan hidup } \\
\text { rukun dengan pemeluk agama lain. }\end{array}$ \\
\hline 2. & Jujur & $\begin{array}{l}\text { Perilaku yang didasarkan pada upaya menjadikan dirinya sebagai orang } \\
\text { yang selalu dapat dipercaya dalam perkataan, tindakan, dan pekerjaan. }\end{array}$ \\
\hline 3. & Toleransi & $\begin{array}{l}\text { Sikap dan tindakan yang menghargai perbedaan agama, suku, etnis, } \\
\text { pendapat, sikap, dan tindakan orang lain yang berbeda dari dirinya. }\end{array}$ \\
\hline 4. & Disiplin & $\begin{array}{l}\text { Tindakan yang menunjukkan perilaku tertib dan patuh pada berbagai } \\
\text { ketentuan dan peraturan. }\end{array}$ \\
\hline 5. & Kerja Keras & $\begin{array}{l}\text { Perilaku yang menunjukkan upaya sungguh-sungguh dalam mengatasi } \\
\text { berbagai hambatan belajar dan tugas, serta menyelesaikan tugas } \\
\text { dengan sebaik-baiknya. }\end{array}$ \\
\hline 6. & Kreatif & $\begin{array}{l}\text { Berpikir dan melakukan sesuatu untuk menghasilkan cara atau hasil } \\
\text { baru dari sesuatu yang telah dimiliki. }\end{array}$ \\
\hline 7. & Mandiri & $\begin{array}{l}\text { Sikap dan perilaku yang tidak mudah tergantung pada orang lain dalam } \\
\text { menyelesaikan tugas-tugas. }\end{array}$ \\
\hline 8. & Demokratis & $\begin{array}{l}\text { Cara berfikir, bersikap, dan bertindak yang menilai sama hak dan } \\
\text { kewajiban dirinya dan orang lain. }\end{array}$ \\
\hline 9. & Rasa Ingin Tahu & $\begin{array}{l}\text { Sikap dan tindakan yang selalu berupaya untuk mengetahui lebih } \\
\text { mendalam dan meluas dari sesuatu yang dipelajarinya, dilihat, dan } \\
\text { didengar. }\end{array}$ \\
\hline 10. & Semangat Kebangsaan & $\begin{array}{l}\text { Cara berpikir, bertindak, dan berwawasan yang menempatkan kepen- } \\
\text { tingan bangsa dan negara di atas kepentingan diri dan kelompoknya. }\end{array}$ \\
\hline 11. & Cinta Tanah Air & $\begin{array}{l}\text { Cara berfikir, bersikap, dan berbuat yang menunjukkan kesetiaan, } \\
\text { kepedulian, dan penghargaan yang tinggi terhadap bahasa, lingkungan } \\
\text { fisik, sosial, budaya, ekonomi, dan politik bangsa. }\end{array}$ \\
\hline 12. & Menghargai Prestasi & $\begin{array}{l}\text { Sikap dan tindakan yang mendorong dirinya untuk menghasilkan sesuatu } \\
\text { yang berguna bagi masyarakat, dan mengakui, serta menghormati } \\
\text { keberhasilan orang lain. }\end{array}$ \\
\hline 13. & Bersahabat/Komunikatif & $\begin{array}{l}\text { Tindakan yang memperlihatkan rasa senang berbicara, bergaul, dan } \\
\text { bekerja sama dengan orang lain. }\end{array}$ \\
\hline 14. & Cinta Damai & $\begin{array}{l}\text { Sikap, perkataan, dan tindakan yang menyebabkan orang lain merasa } \\
\text { senang dan aman atas kehadiran dirinya. }\end{array}$ \\
\hline 15 . & Gemar Membaca & $\begin{array}{l}\text { Kebiasaan menyediakan waktu untuk membaca berbagai bacaan yang } \\
\text { memberikan kebajikan bagi dirinya. }\end{array}$ \\
\hline 16. & Peduli Lingkungan & $\begin{array}{l}\text { Sikap dan tindakan yang selalu berupaya mencegah kerusakan pada } \\
\text { lingkungan alam di sekitarnya, dan mengembangkan upaya-upaya untuk } \\
\text { memperbaiki kerusakan alam yang sudah terjadi. }\end{array}$ \\
\hline 17. & Peduli Sosial & $\begin{array}{l}\text { Sikap dan tindakan yang selalu ingin memberi bantuan pada orang lain } \\
\text { dan masyarakat yang membutuhkan. }\end{array}$ \\
\hline 18. & Tanggung-jawab & $\begin{array}{l}\text { Sikap dan perilaku seseorang untuk melaksanakan tugas dan } \\
\text { kewajibannya, yang seharusnya dia lakukan, terhadap diri sendiri, } \\
\text { masyarakat, lingkungan (alam, sosial dan budaya), negara dan Tuhan } \\
\text { Yang Maha Esa. }\end{array}$ \\
\hline
\end{tabular}




\section{Prinsip dan Pendekatan Pengembangan Pendidikan Karakter}

Pendidikan karakter bukan merupakan mata pelajaran baru yang berdiri sendiri, bukan pula dimasukkan sebagai standar kompetensi dan kompetensi dasar baru, tetapi terintegrasi ke dalam mata pelajaran yang sudah ada, pengembangan diri, dan budaya sekolah (Pusat Kurikulum, 2010), serta muatan lokal (Widyastono, 2010). Oleh karena itu, guru dan sekolah perlu mengintegrasikan nilai-nilai yang dikembangkan dalam pendidikan karakter ke dalam Kurikulum Tingkat Satuan Pendidikan (KTSP), Silabus, dan Rencana Program Pembelajaran (RPP) yang sudah ada.

Prinsip-prinsip yang digunakan dalam pengembangan pendidikan karakter (Pusat Kurikulum, 2010): 1) Berkelanjutan; mengandung makna bahwa proses pengembangan nilai-nilai karakter merupakan sebuah proses yang tiada berhenti, dimulai dari awal peserta didik masuk sampai selesai dari suatu satuan pendidikan, bahkan setelah tamat dan terjun ke masyarakat; 2) Melalui semua mata pelajaran, pengembangan diri, dan budaya sekolah, serta muatan lokal; mensyaratkan bahwa proses pengembangan nilai-nilai karakter dilakukan melalui setiap mata pelajaran, serta dalam setiap kegiatan kurikuler dan ekstrakurikuler; 3) Nilai tidak diajarkan tapi dikembangkan dan dilaksanakan; mengandung makna bahwa materi nilai karakter tidak dijadikan pokok bahasan seperti halnya ketika mengajarkan suatu konsep, teori, prosedur, ataupun fakta dalam mata pelajaran agama, bahasa Indonesia, PKn, IPA, IPS, matematika, pendidikan jasmani dan kesehatan, seni, dan ketrampilan, ataupun mata pelajaran lainnya. Guru tidak perlu mengubah pokok bahasan yang sudah ada, tetapi menggunakan pokok bahasan itu untuk mengembangkan nilai-nilai karakter bangsa. Juga, guru tidak harus mengembangkan proses belajar khusus untuk mengembangkan nilai. Suatu hal yang selalu harus diingat bahwa satu aktivitas belajar dapat digunakan untuk mengembangkan kemampuan dalam ranah kognitif, afektif, dan psikomotor; 4) Proses pendidikan dilakukan peserta didik secara aktif dan menyenangkan; prinsip ini menyatakan bahwa proses pendidikan nilai karakter dilakukan oleh peserta didik bukan oleh guru. Guru menerapkan prinsip "tut wuri handayani" dalam setiap perilaku yang ditunjukkan peserta didik. Prinsip ini juga menyatakan bahwa proses pendidikan dilakukan dalam suasana belajar yang menimbulkan rasa senang dan tidak indoktrinatif. Diawali dengan perkenalan terhadap pengertian nilai yang dikembangkan maka guru menuntun peserta didik agar secara aktif. Hal ini dilakukan tanpa guru mengatakan kepada peserta didik bahwa mereka harus aktif, tapi guru merencanakan kegiatan belajar yang menyebabkan peserta didik aktif merumuskan pertanyaan, mencari sumber informasi, dan mengumpulkan informasi dari sumber, mengolah informasi yang sudah dimiliki, merekonstruksi data, fakta, atau nilai, menyajikan hasil rekonstruksi atau proses pengembangan nilai, menumbuhkan nilai-nilai budaya dan karakter pada diri mereka melalui berbagai kegiatan belajar yang terjadi di kelas, sekolah, dan tugas-tugas di luar sekolah.

\section{Perencanaan Pengembangan Pendidikan Karakter}

Perencanaan dan pelaksanaan pendidikan karakter dilakukan oleh kepala sekolah, guru, tenaga kependidikan (konselor) secara bersamasama sebagai suatu komunitas pendidik dan diterapkan ke dalam kurikulum melalui hal-hal berikut ini.

Pertama, Pengintegrasian dalam mata pelajaran. Pengembangan nilai-nilai pendidikan karakater bangsa diintegrasikan dalam setiap pokok bahasan dari setiap mata pelajaran. Nilainilai tersebut dicantumkan dalam silabus dan RPP. Pengembangan nilai-nilai itu dalam silabus ditempuh melalui cara-cara: (a) mengkaji Standar Komptensi (SK) dan Kompetensi Dasar (KD) pada Standar Isi (SI) untuk menentukan apakah nilainilai karakter bangsa yang tercantum itu sudah tercakup di dalamnya; (b) menggunakan tabel 1 yang memperlihatkan keterkaitan antara SK dan $\mathrm{KD}$ dengan nilai dan indikator untuk menentukan nilai yang akan dikembangkan; (c) mencantumkankan nilai-nilai budaya dan karakter bangsa dalam tabel 1 ke dalam silabus; (d) mencantumkan nilai-nilai yang sudah tertera dalam silabus ke dalam RPP; (e) mengembangkan proses pembelajaran peserta didik secara aktif yang memungkinkan peserta didik memiliki kesempatan melakukan 
internalisasi nilai dan menunjukkannya dalam perilaku yang sesuai; dan (f) memberikan bantuan kepada peserta didik, baik yang mengalami kesulitan untuk menginternalisasi nilai maupun untuk menunjukkannya dalam perilaku.

Kedua, Program Pengembangan Diri. Dalam program pengembngan diri, perencanaan dan pelaksanaan pendidikan karakter dilakukan melalui pengintegrasian ke dalam kegiatan seharihari sekolah yaitu melalui hal-hal: a) Kegiatan rutin sekolah. Kegiatan rutin merupakan kegiatan yang dilakukan peserta didik secara terus menerus dan konsisten setiap saat. Contoh kegiatan ini adalah upacara pada hari besar kenegaraan, pemeriksaan kebersihan badan (kuku, telinga, rambut, dan lain-lain) setiap hari Senin, beribadah bersama atau shalat bersama setiap dhuhur (bagi yang beragama Islam), berdoa waktu mulai dan selesai pelajaran, mengucap salam bila bertemu guru, tenaga kependidikan, atau teman; (b) Kegiatan spontan. Kegiatan spontan yaitu kegiatan yang dilakukan secara spontan pada saat itu juga. Kegiatan ini dilakukan biasanya pada saat guru dan tenaga kependidikan yang lain mengetahui adanya perbuatan yang kurang baik dari peserta didik yang harus dikoreksi pada saat itu juga. Apabila guru mengetahui adanya perilaku dan sikap yang kurang baik maka pada saat itu juga guru harus melakukan koreksi sehingga peserta didik tidak akan melakukan tindakan yang tidak baik itu. Contoh kegiatan itu: membuang sampah tidak pada tempatnya, berteriak-teriak sehingga mengganggu pihak lain, berkelahi, memalak, berlaku tidak sopan, mencuri, berpakaian tidak senonoh. Kegiatan spontan berlaku untuk perilaku dan sikap peserta didik yang tidak baik dan yang baik sehingga perlu dipuji, misalnya: memperoleh nilai tinggi, menolong orang lain, memperoleh prestasi dalam olah raga atau kesenian, berani menentang atau mengkoreksi perilaku teman yang tidak terpuji.

Ketiga, Keteladanan. Keteladanan adalah perilaku dan sikap guru dan tenaga kependidikan yang lain dalam memberikan contoh terhadap tindakan-tindakan yang baik sehingga diharapkan menjadi panutan bagi peserta didik untuk mencontohnya. Jika guru dan tenaga kependidikan yang lain menghendaki agar peserta didik berperilaku dan bersikap sesuai dengan nilai-nilai budaya dan karakter bangsa maka guru dan tenaga kependidikan yang lain adalah orang yang pertama dan utama memberikan contoh berperilaku dan bersikap sesuai dengan nilai-nilai itu. Misalnya, berpakaian rapi, datang tepat pada waktunya, bekerja keras, bertutur kata sopan, kasih sayang, perhatian terhadap peserta didik, jujur, menjaga kebersihan.

Keempat, Pengkondisian. Untuk mendukung keterlaksanaan pendidikan karakter maka sekolah harus dikondisikan sebagai pendukung kegiatan itu. Sekolah harus mencerminkan kehidupan nilainilai budaya dan karakter bangsa yang diinginkan. Misalnya, toilet yang selalu bersih, bak sampah ada di berbagai tempat dan selalu dibersihkan, sekolah terlihat rapi dan alat belajar ditempatkan teratur.

\section{Muatan Lokal}

Muatan lokal merupakan kegiatan kurikuler untuk mengembangkan kompetensi yang disesuaikan dengan ciri khas dan potensi daerah, termasuk keunggulan daerah, yang materinya tidak sesuai menjadi bagian dari mata pelajaran lain dan atau teerlalu banyak sehingga harus menjadi mata pelajaran tersendiri. Substansi muatan lokal ditentukan oleh satuan pendidikan, tidak terbatas pada mata pelajaran keterampilan (BSNP, 2006).

Dalam hubungannya dengan pendidikan karakter, muatan lokal dapat berupa Kesenian Daerah, Nyanyian Daerah, Bahasa Daerah, Adat dan Budaya Daerah. Seperti dinyatakan Anita Lie (2010a) pada mata pelajaran kesenian daerah, siswa diajak mengenal dan mempraktekkan beragam peninggalan seni budaya daerah, falsafah budaya, dan manfaatnya.

\section{Budaya Sekolah}

Budaya sekolah adalah suasana kehidupan sekolah tempat peserta didik berinteraksi dengan sesamanya, guru dengan guru, konselor dengan sesamanya, pegawai administrasi dengan sesamanya, dan antaranggota kelompok masyarakat sekolah. Interaksi internal kelompok dan antarkelompok terikat oleh berbagai aturan, norma, moral serta etika bersama yang berlaku di suatu sekolah. Kepemimpinan, keteladanan, keramahan, toleransi, kerja keras, disiplin, kepedulian sosial, kepedulian lingkungan, rasa 
kebangsaan, dan tanggung jawab merupakan nilai-nilai yang dikembangkan dalam budaya sekolah.

Pengembangan nilai-nilai pendidikan karakter dalam budaya sekolah mencakup kegiatankegiatan yang dilakukan kepala sekolah, guru, konselor, tenaga administrasi ketika berkomunikasi dengan peserta didik dan menggunakan fasilitas sekolah.

\section{Pengembangan Proses Pembelajaran}

Pembelajaran pendidikan karakter menggunakan pendekatan proses belajar peserta didik secara aktif dan berpusat pada anak; dilakukan melalui berbagai kegiatan di kelas, sekolah, dan masyarakat.

Kegiatan di Kelas, pengembangan nilai-nilai tertentu seperti kerja keras, jujur, toleransi, disiplin, mandiri, semangat kebangsaan, cinta tanah air, dan gemar membaca dapat melalui kegiatan belajar yang biasa dilakukan guru. Untuk pegembangan beberapa nilai lain seperti peduli sosial, peduli lingkungan, rasa ingin tahu, dan kreatif memerlukan upaya pengkondisian sehingga peserta didik memiliki kesempatan untuk memunculkan perilaku yang menunjukkan nilainilai itu.

Kegiatan di Sekolah, melalui kegiatan yang dapat dimasukkan ke dalam program sekolah adalah lomba vocal group antarkelas tentang lagulagu bertema cinta tanah air, pagelaran seni, lomba pidato bertema budaya dan karakter bangsa, pagelaran bertema budaya dan karakter bangsa, lomba olah raga antarkelas, lomba kesenian antarkelas, pameran hasil karya peserta didik bertema budaya dan karakter bangsa, pameran foto hasil karya peserta didik bertema budaya dan karakter bangsa, lomba membuat tulisan, lomba mengarang lagu, melakukan wawancara kepada tokoh yang berkaitan dengan budaya dan karakter bangsa, mengundang berbagai narasumber untuk berdiskusi, gelar wicara, atau berceramah yang berhubungan dengan budaya dan karakter bangsa.

Kegiatan di luar sekolah, melalui kegiatan ekstrakurikuler dan kegiatan lain yang diikuti oleh seluruh atau sebagian peserta didik, yang dirancang sejak awal tahun pelajaran, dan dimasukkan ke dalam Kalender Akademik. Misalnya, kunjungan ke tempat-tempat yang menumbuhkan rasa cinta terhadap tanah air, menumbuhkan semangat kebangsaan, melakukan pengabdian masyarakat untuk menumbuhkan kepedulian dan kesetiakawanan sosial (membantu mereka yang tertimpa musibah banjir, memperbaiki atau membersihkan tempat-tempat umum, membantu membersihkan atau mengatur barang di tempat ibadah tertentu).

\section{Indikator Sekolah dan Kelas.}

Indikator sekolah dan kelas adalah penanda yang digunakan oleh kepala sekolah, guru, dan personalia sekolah dalam merencanakan, melaksanakan, dan mengevaluasi sekolah sebagai lembaga pelaksana pendidikan karakter.

Untuk mengetahui bahwa suatu sekolah itu telah mengimplementasikan pendidikan karakter, maka ditetapkan indikator sekolah dan kelas antara lain seperti berikut :

Tabel 2. Indikator Keberhasilan Sekolah dan Kelas dalam Implementasi Pendidikan Karakter

\begin{tabular}{|c|c|c|c|}
\hline NILAI & DESKRIPSI & INDIKATOR SEKOLAH & INDIKATOR KELAS \\
\hline Religius & $\begin{array}{l}\text { Sikap dan perilaku yang } \\
\text { patuh dalam melak- } \\
\text { sanakan ajaran agama } \\
\text { yang dianutnya, toleran } \\
\text { terhadap pelaksanaan } \\
\text { ibadah agama lain, ser- } \\
\text { ta hidup rukun dengan } \\
\text { pemeluk agama lain. }\end{array}$ & $\begin{array}{l}\text { - Merayakan hari-hari } \\
\text { besar keagamaan. } \\
\text { - Memiliki fasilitas yang } \\
\text { dapat digunakan } \\
\text { untuk beribadah. } \\
\text { - Memberikan } \\
\text { kesempatan kepada } \\
\text { semua peserta didik } \\
\text { untuk melaksanakan } \\
\text { ibadah. }\end{array}$ & $\begin{array}{l}\text { - Berdoa sebelum dan } \\
\text { sesudah pelajaran. } \\
\text { - Memberikan } \\
\text { kesempatan kepada } \\
\text { semua peserta didik } \\
\text { untuk melaksanakan } \\
\text { ibadah. }\end{array}$ \\
\hline
\end{tabular}




\section{Simpulan dan Saran Simpulan}

Berdasar masalah, kajian literatur, dan pembahasan di atas, maka dapat dirumuskan simpulan berikut: 1) Pendidikan di Indonesia masih terfokus pada aspek-aspek kognitif atau akademik, sedangkan aspek soft skills atau non-akademik yang merupakan unsur utama pendidikan karakter selama ini masih kurang mendapatkan perhatian; 2) Pendidikan karakter dimaknai sebagai pendidikan yang mengembangkan nilainilai karakter pada diri peserta didik sehingga mereka memiliki nilai dan karakter sebagai karakter dirinya, menerapkan nilai-nilai tersebut dalam kehidupan dirinya, sebagai anggota masyarakat dan warganegara yang religius, nasionalis, produktif, dan kreatif; 3) Tujuan pendidikan karakter adalah: (a) mengembangkan potensi kalbu/nurani/afektif peserta didik sebagai manusia dan warganegara yang memiliki nilai-nilai karakter bangsa, (b) mengembangkan kebiasaan dan perilaku peserta didik yang terpuji dan sejalan dengan nilai-nilai universal dan tradisi budaya bangsa yang religius, (c) menanamkan jiwa kepemimpinan dan tanggung jawab peserta didik seagai generasi penerus bangsa; (d) mengembangkan kemampuan peserta didik menjadi manusia yang mandiri, kreatif, berwawasan keangsaan; dan (e) mengembangkan lingkungan kehidupan sekolah sebagai lingkungan elajar yang aman, jujur, penuh kreativitas dan persahaatan, serta dengan rasa kebangsaan yang tinggi dan penuh kekuatan; dan 4) Implementasi pendidikan karakter di sekolah dasar dapat diintegrasikan ke dalam mata pelajaran yang sudah ada, muatan lokal, pengembangan diri, dan budaya sekolah.

\section{Saran}

Berdasar simpulan di atas, dirumuskan beberapa saran: 1) Pembelajaran di sekolah hendaknya tidak hanya menekankan pada aspek-aspek kognitif atau akademik saja, melainkan juga harus menekankan pada soft skills atau non-akademik (afektif dan psikomotorik) yang merupakan unsur utama pendidikan karakter; 2) Kelulusan siswa hendaknya tidak hanya ditentukan oleh penilaian aspek kognitif saja, melainkan juga penilaian afektif dan psikomotor; dan 3) Pusat Kurikulum Balitbang Kemendiknas, yang merupakan leading sector pengembangan pendidikan karakter di lingkungan Kemendiknas hendaknya segera melakukan pelatihan pendidikan karakter bagi guru, kepala sekolah, pengawas sekolah, pejabat dinas pendidikan kabupaten/kota, pejabat dinas pendidikan provinsi, dan pejabat kementerian pendidikan nasional, serta stake holder lainnya yang relevan.

\section{Pustaka Acuan}

Badan Standar Nasional Pendidikan. (2006). Panduan Penyusunan Kurikulum Tingkat Satuan Pendidikan.

Departemen Pendidikan Nasional. 2003. Undang-Undang Nomor 20 Tahun 2003 tentang Sistim Pendidikan Nasional.

Departemen Pendidikan Nasional. 2006. Peraturan Menteri Pendidikan Nasional Nomor 23 Tahun 2006 tentang Standar Kompetensi Lulusan.

Departemen Pendidikan Nasional. 2008. Kamus Bahasa Indonesia. Jakarta: Pusat Bahasa.

Bohlin, E. Karen., Deborah Farmer, \& Kevin Ryan, 2001. Building Character inSchool Resource Guide, San Fransisco, Jossey Bass. .

Jalal, Fasli. 2010a. Kebijakan Nasional Pendidikan Karakter: Tiga Stream Pendekatan. Jakarta: Kementerian Pendidikan Nasional.

Jalal, Fasli. 2010b. Pendidikan Karakter Diintegrasikan, Kompas.com, Minggu, 31 Agustus, 2010. Diunduh 30 Januari 2011.

Kementerian Pendidikan Nasional. 2010. Bahan Pelatihan Penguatan Metodologi Pembelajaran Berdasarkan Nilai-Nilai Budaya Untuk Membentuk Daya Saing dan Karakter Bangsa. Jakarta: Pusat Kurikulum, Badan Penelitian dan Pengembangan.

Lie, Anita. 2010a. Pendidikan Karakter Sulit Diterapkan. KOMPAS.com, 15 Januari 2010. Diunduh 30 Januari 2011. 
Lie, Anita. 2010b. Guru Belum Terapkan Pendidikan Karakter. http: //buntetpesantren.org/index, 16 Januari 2010. Diunduh 31 Januari 2011.

Menteri Pendidikan Nasional. 2010. Penerapan Pendidikan Karakter Dimulai di SD. http: // www.antaranews.com/berita/1273933824/mendiknas, Sabtu, 15 Mei 2010. Diunduh 30 Januari 2011.

Phillips, Simon., 2008. Refleksi Karakter Bangsa - Makalah. Jakarta: tanpa penerbit.

Widyastono, Herry. 2010. Bahan Pelatihan Penyelenggaraan Pendidikan Karakter di Sekolah. Jakarta: Yayasan Pendidikan Masjid Panglima Besar Jenderal Sudirman.

Undang-Undang Dasar Republik Indonesia tahun 1945 